\title{
Scalable Synthesis of Salt-free Quaternary Ammonium Carboxylate Catanionic Surfactants
}

\author{
Žiga Medoš, Miha Virant, Urša Štanfel, Boštjan Žener, Janez Košmrlj* \\ and Marija Bešter-Rogač
}

Faculty of Chemistry and Chemical Technology, Večna pot 113, University of Ljubljana, SI-1000 Ljubljana, Slovenia

*Corresponding author: E-mail: janez.kosmrlj@fkkt.uni-li.si

Tel: +38614798558

E-mail: marija.bester@fkkt.uni-lj.si

Tel: +38614798537

Received: 07-16-2019

\begin{abstract}
Surfactants in commercial products commonly contain catanionic mixtures thus many studies of aqueous surfactant mixtures have been carried out. However, hardly any studies have been dedicated to pure catanionic surfactants often termed salt-free catanionic surfactants. One of the difficulties is in acquirement of samples with required purity due to difficult separation of these compounds from inorganic salts. In this work we present an alternative method of synthesis using dimethyl carbonate as the alkylating agent in order to obtain alkyl trimethylammonium alkanecarboxylates with medium alkyl chain lengths (6-10).
\end{abstract}

Keywords: Synthesis; surfactants; salt-free; catanionics; quaternization

\section{Introduction}

Commercial surfactants are commonly a mixture of cationic, anionic and non-ionic surfactants due to their enhanced performance as mixtures. ${ }^{1,2}$ Therefore, along the studies of non-ionic and ionic surfactants in their pure form as well as in binary aqueous solutions, significant focus has been dedicated to aqueous mixtures of cationic and anionic surfactants - catanionic mixtures. An interesting group of catanionic surfactants are salt-free catanionics, where often the challenge of preparing these surfactants in their pure form is the removal of all inorganic salts upon mixing the parent cation and anion salts. There are three main methods to remove inorganic salts from equimolar catanionic mixtures: (1) ion-exchange columns are used to prepare acids and hydroxides and subsequently mixed; (2) liquid-liquid extraction in organic phase and (3) precipitation method. ${ }^{3}$ When surfactants are poorly soluble in organic solvents precipitation is generally easily achieved. On the contrary, if solubility is limited in polar solvents liquid-liquid extraction is possible. However, many surfactants, especially those interesting for application, are soluble in both, organic and aqueous media. This limits the separa- tion techniques to ion-exchange columns or the precipitation of silver halides from water solutions. Unfortunately, these two approaches are not economically viable and some contamination with inorganic salt can still occur. This can have significant impact on some of the surfactant's properties and can crucially affect studied physical and aggregation properties of aqueous solutions. ${ }^{4-6}$ Thus, the development of novel and more effective methods of synthesis is required.

In this work we present two synthetic procedures to prepare alkyltrimethylammonium alkanecarboxylate catanionic surfactants (Figure 1). Generally, the synthesis of quaternary ammonium surfactants starts with ammonia or substituted amine precursor. It is alkylated in two or more steps with the last step being quaternization. Most studied and produced quaternary ammonium surfactants are alkyltrimethylammonium halides followed by dialkyldimethylammonium halides (gemeni surfactants). ${ }^{7}$ Their aqueous solutions are generally more stable than quaternary ammonium surfactants with remaining hydrogen(s) on quaternary ammonium. Quaternization can be achieved by the Menshutkin reaction where tertiary amine is reacted with haloalkane. However, halide free methods are preferred for industrial application. 


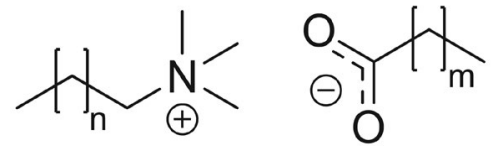

Figure 1. $N$-alkyl- $N, N, N$-trimethylammonium alkanecarboxylates.

Recently, Jiang et. al. presented a synthetic procedure for the preparation of salt-free quaternary ammonium carboxylates using dimethyl carbonate (DMC) as alkylating agent of appropriate tertiary amines, with one or two alkyl chains exceeding 12 carbon atoms and a short-chain carboxylate anion (acetate, propionate, lactate). ${ }^{8}$ They expanded the scope to long-chain catanionic surfactants in the follow-up papers, namely tetradecyltrimethylammonium alkanecarboxylates (hexanoate, octanoate, decanoate, dodecanoate, tetradecanoate $)^{9}$ and alkyl (decyl, dodecyl, tetradecyl, hexadecyl, octadecyl) trimethylammonium decanoates. ${ }^{10}$ DMC represents an attractive eco-friendly alternative to methyl halides. ${ }^{11}$

However, additional challenges emerge when both alkyl chains are shorter than 10 carbon atoms. Mainly, due to increased solubility in majority of polar and non-polar solvents the usual purification methods of precipitation, recrystallization and liquid-liquid extraction become less efficient or impossible. Additionally, the commercial price of tertiary amines, required in the most common synthesis approach, increases with shorter chains. Therefore, in this work we present low cost synthetic alternative starting with a secondary amine to produce quaternary ammonium carboxylate surfactants with alkyl chains between 6 and 10 carbon atoms long.

Synthesis of decyltrimethylammonium alkanecarboxylates (acetate, butanoate, hexanoate, octanoate, nonanoate, decanoate, undecanoate) has also been reported by reacting quaternary ammonium halides with silver hydroxide. After precipitation of the silver halide salts, the resulting hydroxide solutions were reacted with carboxylic acid. ${ }^{12}$ For large scale application silver salts are not economically viable, therefore we present a competitive approach through precipitation of $\mathrm{KCl}$ from ethanol. We compare the thermal properties of products obtained by both procedures.

\section{Experimental}

\section{1. General Information}

The reagents and solvents in general procedures were used as obtained from the commercial sources (Merck), unless noted otherwise. Octanoic acid (4b) and decanoic acid (4c) were recrystallized from ethanol by addition of acetone. IR spectra were obtained with a Perkin-Elmer Spectrum 100, equipped with a Specac Golden Gate Diamond ATR as a solid sample support. High resolution mass spectra (HRMS) were recorded on Agilent 6224 time-of-flight (TOF) mass spectrometer equipped with a double orthogo- nal electrospray source at atmospheric pressure ionization (ESI) coupled to an HPLC instrument. ${ }^{1} \mathrm{H},{ }^{13} \mathrm{C}$ and ${ }^{15} \mathrm{~N}$ NMR spectra were recorded with a Bruker Avance III 500 $\mathrm{MHz}$ NMR (at $500 \mathrm{MHz}, 126 \mathrm{MHz}$ and $51 \mathrm{MHz}$, respectively) instrument at $296 \mathrm{~K}$ in DMSO- $d_{6}$ using TMS as an internal standard. Proton and carbon spectra were referenced to the residual chloroform shifts of $7.26 \mathrm{ppm}$ and $77.16 \mathrm{ppm}$, respectively. ${ }^{13}$ Assignments of proton, carbon and nitrogen resonances were performed by $2 \mathrm{D}$ NMR techniques $\left({ }^{1} \mathrm{H}-{ }^{1} \mathrm{H}\right.$ $g s$-COSY, ${ }^{1} \mathrm{H}-{ }^{13} \mathrm{C} g s-\mathrm{HSQC},{ }^{1} \mathrm{H}-{ }^{13} \mathrm{C} g s-\mathrm{HMBC}$ and ${ }^{1} \mathrm{H}-{ }^{15} \mathrm{~N}$ $g s-\mathrm{HMBC})$. Carbon resonances without labels belong to the chain carbons and could not have been differentiated. Thermogravimetric (TG) measurements were performed on a Mettler Toledo TGA/DSC1 Instrument in the temperature range from 25 to $400{ }^{\circ} \mathrm{C}$ under dynamic air flow $\left(100 \mathrm{~cm}^{3}\right.$ $\mathrm{min}^{-1}$ ) with a heating rate of $5 \mathrm{~K} \mathrm{~min}^{-1}$. Approximately 3-5 $\mathrm{mg}$ of sample was weighed into a $150 \mu \mathrm{L}$ platinum crucible and the baseline was subtracted. Differential scanning calorimetry (DSC) measurements were performed separately on a Mettler Toledo DSC 1 Instrument in $40 \mu \mathrm{L}$ aluminium crucibles under the same conditions.

\section{2. Synthesis}

\section{Alkyltrimethylammonium Chlorides $\mathbf{3 a}-\boldsymbol{c}$}

In a $200 \mathrm{~mL}$ autoclave chloroalkanes $2 \mathbf{a}-\mathbf{c}(0.21 \mathrm{~mol}$, $1 \mathrm{eq})$ were mixed with $33 \%$ trimethylamine solution in ethanol $(1,100 \mathrm{~mL}, 2 \mathrm{eq})$. The mixture was stirred in an oil bath at $80{ }^{\circ} \mathrm{C}$ for 3 days. Excess 1 and solvents were removed under reduced pressure. Products were dissolved in minimal amount of ethanol required (approx. $5 \mathrm{~mL}$ ) and recrystallized by addition of ethyl acetate $(100 \mathrm{~mL})$. The precipitates were filtered and washed with diethyl ether $(50 \mathrm{~mL})$ and subsequently dried under reduced pressure to yield products in 50\% average yield. Products 3 are very hygroscopic which reduces the yield of recrystallization in open air (3a 26\%, 3b 53\%, 3c 55\%).

\section{Alkyltrimethylammonium Carboxylates 5a-e According to Procedure A \\ In the next step, alkyltrimethylammonium chlorides 3a-c as prepared above $(0.07 \mathrm{~mol})$ were dissolved in etha- nol $(20 \mathrm{~mL})$ and weighed precisely. The exact amount of chloride ions was determined by $\mathrm{AgNO}_{3}$ titration of small samples and the required equimolar amounts of carboxylic acids $4 \mathbf{a}-\mathbf{c}$ were weighted and added. $95 \%$ of $\mathrm{KOH}$, re- quired for neutralization, was weighed as solid pellets. Af- ter all of the added solid $\mathrm{KOH}$ dissolved and $\mathrm{KCl}$ precipitat- ed ( 1 hour), the remaining $\mathrm{KOH}$ was titrated as an approximate $0.25 \mathrm{M}$ solution of $\mathrm{KOH}$ in ethanol until po- tential of glass electrode dropped below $-250 \mathrm{mV}$ which was previously determined as the potential of the inflection point. Solutions were filtered to separate the filtrate con- taining the products from the precipitated $\mathrm{KCl}$. Filtrates were concentrated under reduced pressure subsequently precipitating more $\mathrm{KCl}$ which was filtered to obtain filtrate}


containing desired alkyltrimethylammonium carboxylates $5 \mathbf{a}-\mathbf{e}$ in quantitative yields. Solutions were dried first under reduced pressure and followed by high vacuum. However, due to increased solubility of $\mathrm{KCl}$ in the presence of the products up to $3 \%$ of $\mathrm{KCl}$ remains in the final product as determined by $\mathrm{AgNO}_{3}$ titration and TG analysis.

\section{Alkyldimethylamines $\mathbf{8 a}-\boldsymbol{c}$}

Bromoalkanes 7 (bromohexane (7a) $2.3 \mathrm{~mol}$; bromooctane (7b) 1.9 mol; bromodecane (7c) $1.6 \mathrm{~mol}$; 1 eq) were mixed with toluene $(300 \mathrm{~mL})$ in a $3 \mathrm{~L}$ autoclave. Then $40 \% \mathrm{~N}, \mathrm{~N}$-dimethylamine (6) solution in water $(500 \mathrm{~mL}$, approx. 2 eq) was added. An excess amount of $\mathrm{NaOH}(200$ $\mathrm{mL}$ ) was added as a $50 \%$ aqueous solution. The mixtures were stirred and heated to $60^{\circ} \mathrm{C}$ for 3 days. After the reaction was completed the reaction mixture separated in two layers. The organic phase containing products was separated from water phase and concentrated under reduced pressure. The products were washed several times with water $(5 \times 20 \mathrm{~mL})$ and distilled under reduced pressure to ensure separation from inorganic byproducts and to remove toluene (8a 70\%, 8b 90\%, 8c 95\%). While amine 8c can be dried on a vacuum line with minimal loss due to evaporation, the distillation results in better overall yield. The presence of toluene in product is not problematic, as it is removed in the following steps.

\section{Alkyltrimethylammonium Methylcarbonates $\mathbf{9 a}-\boldsymbol{c}$}

In a $50 \mathrm{~mL}$ autoclave alkyldimethylamines $\mathbf{8 a}-\mathbf{c}$ as prepared above $(0.2 \mathrm{~mol}, 1 \mathrm{eq})$ were mixed with dimethyl carbonate $\left(\mathrm{Me}_{2} \mathrm{CO}_{3}, 0.3 \mathrm{~mol}, 1.5 \mathrm{eq}\right)$ and methanol $(20 \mathrm{~mL})$ as solvent. Mixtures were stirred at $120^{\circ} \mathrm{C}$ for 2 days or 110 ${ }^{\circ} \mathrm{C}$ for 3 days. Excess $\mathrm{Me}_{2} \mathrm{CO}_{3}$ and solvent were removed under reduced pressure. Alkyltrimethylammonium methyl carbonates with traces of hydrogencarbonate analogues were recrystallized from ethyl acetate. The pure products 9 were obtained after recrystallization $(\mathbf{9 a} 50 \%, 9 b$ 70\%, 9c $90 \%$ ). Yields are primarily lowered by loss during purification however it should be noted that recrystallization in this step is not strictly necessary as the organic impurities are also successfully removed by recrystallization in the final step of the procedure B thus potentially increasing yield.

\section{Alkyltrimethylammonium Carboxylates $5 \boldsymbol{a}-\boldsymbol{f}$ According to Procedure B}

In a round-bottomed flask alkyltrimethylammonium methylcarbonates $9 \mathbf{a}-\mathbf{c}(0.03 \mathrm{~mol})$ and carboxylic acids $\mathbf{4}$ $(0.03 \mathrm{~mol})$ were weighed. Small amount of methanol (2 $\mathrm{mL}$ ) was added to increase solubility and speed up the reactions. After stirring for an hour at room temperature, methanol was removed under reduced pressure and the products isolated as white solids. For analysis and further research application, the products were recrystallized using acetonitrile. If significant excess of 4 (more than 2\%) was used or methanol was not completely removed the mixture dissolved fully in acetonitrile. The longer the alkyl chains on cation and anion the better the yield due to the poorer solubility in acetonitrile and lower hygroscopicity $(\mathbf{5 a} 70 \%$, 5b $90 \%, 5$ c $80 \%$, 5d $40 \%$, 5e 60\%, 5f 15\%). The attempt to make decyltrimethylammonium acetate was unsuccessful because of the complete solubility in acetonitrile.

\section{3. Characterization of Alkyltrimethylammonium Carboxylates $\mathrm{N}$-Hexyl- $\mathrm{N}, \mathrm{N}, \mathrm{N}$-trimethylammonium Decanoate (5a)}
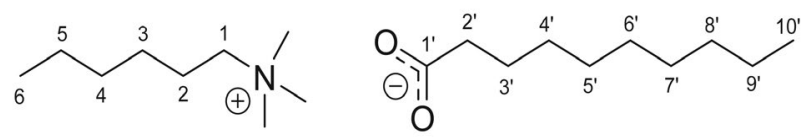

Prepared according to the general procedure B. White solid (11.5 g, 35\%). IR 3473, 3393, 3020, 2920, 2852, 1572, 1377, 1055, 963, $643 \mathrm{~cm}^{-1} .{ }^{1} \mathrm{H}$ NMR $(500 \mathrm{MHz}$, $\left.\mathrm{CDCl}_{3}\right) \delta 3.42-3.35\left(\mathrm{~m}, 2 \mathrm{H}, \mathrm{CH}_{2}-1\right), 3.32\left(\mathrm{~s}, 9 \mathrm{H}, \mathrm{NMe}_{3}\right.$ ), 2.14-2.06 (m, $\left.2 \mathrm{H}, \mathrm{CH}_{2}-2^{\prime}\right), 1.75-1.64\left(\mathrm{~m}, 2 \mathrm{H}, \mathrm{CH}_{2}-2\right)$, 1.59-1.48 (m, 2H, $\left.\mathrm{CH}_{2}-3^{\prime}\right), 1.38-1.15\left(\mathrm{~m}, 18 \mathrm{H}, \mathrm{CH}_{2^{-}}\right.$ chain), $0.92-0.78\left(\mathrm{~m}, 6 \mathrm{H}, \mathrm{CH}_{3}-10\right.$ ' and $\left.\mathrm{CH}_{3}-6\right) .{ }^{13} \mathrm{C} \mathrm{NMR}$ $\left(126 \mathrm{MHz}, \mathrm{CDCl}_{3}\right) \delta 179.8$ (COO), 66.9 (30.21), 53.2 $\left(\mathrm{NMe}_{3}\right), 39.4$ (C-2'), 32.0, 31.4, 30.2, 29.9, 29.8, 29.50, 27.3, 26.0, 23.2, 22.8, 22.5, $14.2\left(\mathrm{CH}_{3}-6 / \mathrm{CH}_{3}-10^{\prime}\right), 14.0\left(\mathrm{CH}_{3}-6 /\right.$ $\left.\mathrm{CH}_{3}-10^{\prime}\right) .{ }^{15} \mathrm{~N}$ NMR $\left(51 \mathrm{MHz}, \mathrm{CDCl}_{3}\right) \delta 49.5\left(\mathrm{NMe}_{3}\right)$. HRMS (ESI+): calcd. for $\mathrm{C}_{9} \mathrm{H}_{22} \mathrm{~N}^{+}\left[\mathrm{M}^{+}\right]$144.1747, found 144.1749. HRMS (ESI-): calcd. for $\mathrm{C}_{10} \mathrm{H}_{19} \mathrm{O}_{2}^{-}$[M"] 171.1391, found 171.1389 .

$\mathrm{N}$-Octyl- $\mathrm{N}, \mathrm{N}, \mathrm{N}$-trimethylammonium Decanoate (5b)
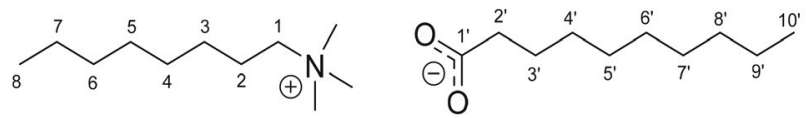

Prepared according to the general procedure B. White solid (14.7 g, 63\%). IR 3317, 3119, 3032, 2919, 2851, 1657, 1569, 1380, 972, $756 \mathrm{~cm}^{-1} .{ }^{1} \mathrm{H}$ NMR $(500 \mathrm{MHz}$, $\left.\mathrm{CDCl}_{3}\right) \delta 3.43-3.38\left(\mathrm{~m}, 2 \mathrm{H}, \mathrm{CH}_{2}-1\right), 3.38-3.31(\mathrm{~m}, 9 \mathrm{H}$, $\mathrm{NMe}_{3}$ ), 2.19-2.05 (m, 2H, $\left.\mathrm{CH}_{2}-2^{\prime}\right), 1.76-1.61(\mathrm{~m}, 2 \mathrm{H}$, $\left.\mathrm{CH}_{2}-2\right), 1.60-1.49\left(\mathrm{~m}, 2 \mathrm{H}, \mathrm{CH}_{2}-3^{\prime}\right), 1.41-1.13(\mathrm{~m}, 22 \mathrm{H}$, $\mathrm{CH}_{2}$-chain), $0.89-0.79\left(\mathrm{~m}, 6 \mathrm{H}, \mathrm{CH}_{3}-8\right.$ and $\left.\mathrm{CH}_{3}-10\right) .{ }^{13} \mathrm{C}$ NMR (126 MHz, $\left.\mathrm{CDCl}_{3}\right) \delta 179.6$ (COO), 66.9 (C-1), 53.2 $\left(\mathrm{NMe}_{3}\right), 39.2$ (C-2'), 32.0, 31.7, 30.2, 29.8, 29.8, 29.5, 29.3, 29.1, 27.3 (C-3'), 26.4, 23.2 (C-2), 22.8, 22.7, $14.2\left(\mathrm{CH}_{3}-8 /\right.$ $\left.\mathrm{CH}_{3}-10^{\prime}\right), 14.1\left(\mathrm{CH}_{3}-8 / \mathrm{CH}_{3}-10^{\prime}\right) .{ }^{15} \mathrm{~N}$ NMR $(51 \mathrm{MHz}$, $\left.\mathrm{CDCl}_{3}\right) \delta 49.7\left(\mathrm{NMe}_{3}\right)$. HRMS (ESI+): calcd. for $\mathrm{C}_{11} \mathrm{H}_{26} \mathrm{~N}^{+}$ $\left[\mathrm{M}^{+}\right]$172.2060, found 172.2057. HRMS (ESI-): calcd. for $\left.\mathrm{C}_{10} \mathrm{H}_{19} \mathrm{O}_{2}^{-}{ }^{-} \mathrm{M}^{-}\right]$171.1391, found 171.1386.

\section{$N$-Decyl- $N, N, N$-trimethylammonium Decanoate (5c)}
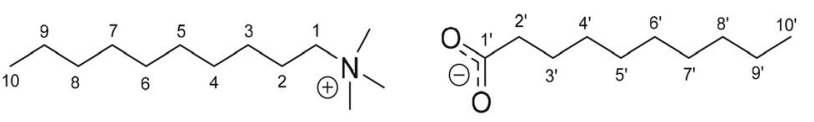

Prepared according to the general procedure B. White solid (25.3 g, 72\%). IR 3429, 3348, 3195, 3119, 3032, 
2916, 2850, 1656, 1566, $1387 \mathrm{~cm}^{-1} .{ }^{1} \mathrm{H}$ NMR $(500 \mathrm{MHz}$, $\left.\mathrm{CDCl}_{3}\right) \delta 3.42-3.35\left(\mathrm{~m}, 2 \mathrm{H}, \mathrm{CH}_{2}-1\right), 3.32$ (s, 9H, $\mathrm{NMe}_{3}$ ), 2.16-2.07 (m, 2H, $\mathrm{CH}_{2}-2$ ) , 1.74-1.63 (m, $\left.2 \mathrm{H}, \mathrm{CH}_{2}-2\right)$, $1.54\left(\mathrm{p}, J=7.2 \mathrm{~Hz}, 2 \mathrm{H}, \mathrm{CH}_{2}-3^{\prime}\right), 1.38-1.14\left(\mathrm{~m}, 26 \mathrm{H}, \mathrm{CH}_{2}-\right.$ chain), 0.91-0.79 (m, 6H, $\mathrm{CH}_{3}-10$ and $\mathrm{CH}_{3}-10$ '). ${ }^{13} \mathrm{C} \mathrm{NMR}$ $\left(126 \mathrm{MHz}, \mathrm{CDCl}_{3}\right) \delta 179.6$ (COO), 66.9 (C-1), 53.2 $\left(\mathrm{NMe}_{3}\right), 39.0$ (C-2'), 32.0, 31.9, 30.2, 29.9, 29.8, 29.54, 29.51, 29.4, 27.2 (C-3'), 26.4, 23.3 (C-2), 22.79, 22.75, 14.22 $\left(\mathrm{CH}_{3}-10 / \mathrm{CH}_{3}-10^{\prime}\right), 14.19\left(\mathrm{CH}_{3}-10 / \mathrm{CH}_{3}-10^{\prime}\right) .{ }^{15} \mathrm{~N}$ NMR $\left(51 \mathrm{MHz}, \mathrm{CDCl}_{3}\right) \delta 49.5\left(\mathrm{NMe}_{3}\right)$. HRMS (ESI+): calcd. for $\mathrm{C}_{13} \mathrm{H}_{30} \mathrm{~N}^{+}\left[\mathrm{M}^{+}\right]$200.2373, found 172.2373. HRMS (ESI-): calcd. for $\mathrm{C}_{10} \mathrm{H}_{19} \mathrm{O}_{2}{ }^{-}\left[\mathrm{M}^{-}\right]$171.1391, found 171.1388.

\section{$\mathrm{N}$-Octyl- $\mathrm{N}, \mathrm{N}, \mathrm{N}$-trimethylammonium Octanoate (5d)}
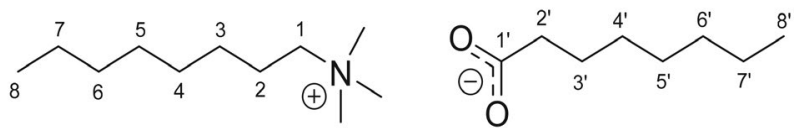

Prepared according to the general procedure $\mathrm{B}$. White solid (10.8 g, 28\%). IR 3510, 3022, 2919, 2851, 1657, 1573, 1378, 974, 918, $773 \mathrm{~cm}^{-1} .{ }^{1} \mathrm{H}$ NMR (500 MHz, $\left.\mathrm{CDCl}_{3}\right) \delta$ 3.43-3.36 (m, 2H, $\left.\mathrm{CH}_{2}-1\right)$, 3.35-3.25 (m, 9H, $\mathrm{NMe}_{3}$ ), 2.162.05 (m, 2H, $\mathrm{CH}_{2}-2$ '), 1.74-1.61 (m, 2H, $\left.\mathrm{CH}_{2}-2\right), 1.59-1.46$ (m, 2H, $\left.\mathrm{CH}_{2}-3^{\prime}\right), 1.35-1.12$ (m, $14 \mathrm{H}, \mathrm{CH}_{2}$-chain), 0.89-0.75 $\left(\mathrm{m}, 6 \mathrm{H}, \mathrm{CH}_{3}-8\right.$ and $\left.\mathrm{CH}_{3}-8^{\prime}\right) .{ }^{13} \mathrm{C} \mathrm{NMR}\left(126 \mathrm{MHz}, \mathrm{CDCl}_{3}\right) \delta$ 179.5 (COO), 66.8 (C-1), 53.1 ( $\left.\mathrm{NMe}_{3}\right), 39.1$ (C-2'), 32.0, 31.7, 30.1, 29.5, 29.3, 29.1, 27.2 (C-3'), 26.3, 23.2 (C-2), 22.8, 22.6, $14.2\left(\mathrm{CH}_{3}-8 / \mathrm{CH}_{3}-8^{\prime}\right), 14.1\left(\mathrm{CH}_{3}-8 / \mathrm{CH}_{3}-8^{\prime}\right) .{ }^{15} \mathrm{~N}$ NMR $\left(51 \mathrm{MHz}, \mathrm{CDCl}_{3}\right) \delta 49.4\left(\mathrm{NMe}_{3}\right)$. HRMS (ESI+): calcd. for $\mathrm{C}_{11} \mathrm{H}_{26} \mathrm{~N}^{+}\left[\mathrm{M}^{+}\right]$172.2060, found 172.2054. HRMS (ESI-): calcd. for $\left.\mathrm{C}_{8} \mathrm{H}_{15} \mathrm{O}_{2}^{-}{ }^{-} \mathrm{M}^{-}\right]$143.1078, found 143.1076.

\section{$N$-Decyl- $N, N, N$-trimethylammonium Octanoate (5e)}
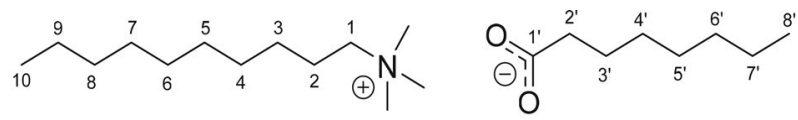

Prepared according to the general procedure B. White solid (16.7 g, 54\%). IR 3464, 3385, 3021, 2919, 2851, 1572, 1380, 915, 772, $722 \mathrm{~cm}^{-1}$. ${ }^{1} \mathrm{H}$ NMR $(500 \mathrm{MHz}$, $\left.\mathrm{CDCl}_{3}\right) \delta 3.45-3.39\left(\mathrm{~m}, 2 \mathrm{H}, \mathrm{CH}_{2}-1\right), 3.40-3.35(\mathrm{~m}, 9 \mathrm{H}$, $\left.\mathrm{NMe}_{3}\right), 2.23-2.11\left(\mathrm{~m}, 2 \mathrm{H}, \mathrm{CH}_{2}-2^{\prime}\right), 1.79-1.67(\mathrm{~m}, 2 \mathrm{H}$, $\left.\mathrm{CH}_{2}-2\right), 1.65-1.53\left(\mathrm{~m}, 2 \mathrm{H}, \mathrm{CH}_{2}-3\right), 1.42-1.18(\mathrm{~m}, 22 \mathrm{H}$, $\mathrm{CH}_{2}$-chain), $0.93-0.81\left(\mathrm{~m}, 6 \mathrm{H}, \mathrm{CH}_{3}-10\right.$ and $\left.\mathrm{CH}_{3}-8^{\prime}\right) .{ }^{13} \mathrm{C}$ NMR (126 MHz, $\left.\mathrm{CDCl}_{3}\right) \delta 180.0$ (COO), $67.1(\mathrm{C}-1), 53.4$ $\left(\mathrm{NMe}_{3}\right), 39.3$ (C-2'), 32.1, 32.0, 30.2, 29.6, 29.53, 29.49, 29.36, 29.34, 27.3 (C-3'), 26.4, 23.3 (C-2'), 22.9, 22.8, 14.3 $\left(\mathrm{CH}_{3}-10 / \mathrm{CH}_{3}-8^{\prime}\right), 14.2\left(\mathrm{CH}_{3}-10 / \mathrm{CH}_{3}-8^{\prime}\right) .{ }^{15} \mathrm{~N}$ NMR (51 $\left.\mathrm{MHz}, \mathrm{CDCl}_{3}\right) \delta 49.7\left(\mathrm{NMe}_{3}\right)$. HRMS (ESI+): calcd. for $\mathrm{C}_{13} \mathrm{H}_{30} \mathrm{~N}^{+}\left[\mathrm{M}^{+}\right]$200.2373, found 172.2375. HRMS (ESI-): calcd. for $\left.\mathrm{C}_{8} \mathrm{H}_{15} \mathrm{O}_{2}^{-}{ }^{-} \mathrm{M}^{-}\right]$143.1078, found 143.1073 .

\section{$N$-Decyl- $N, N, N$-trimethylammonium Hexanoate (5f)}
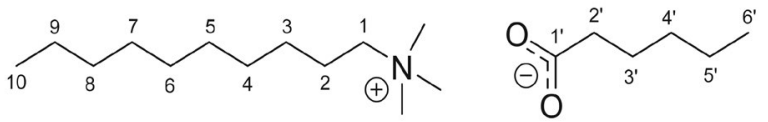

Prepared according to the general procedure $\mathrm{B}$. White solid (2.2 g, 13\%). IR 3359, 3021, 2922, 2854, 1572, $1377,973,918,766,644 \mathrm{~cm}^{-1} .{ }^{1} \mathrm{H}$ NMR $\left(500 \mathrm{MHz}, \mathrm{CDCl}_{3}\right)$

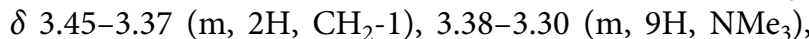
2.21-2.03 (m, $\left.2 \mathrm{H}, \mathrm{CH}_{2}-2^{\prime}\right), 1.76-1.61\left(\mathrm{~m}, 2 \mathrm{H}, \mathrm{CH}_{2}-2\right)$, 1.61-1.50 (m, 2H, $\left.\mathrm{CH}_{2}-3^{\prime}\right), 1.38-1.15\left(\mathrm{~m}, 18 \mathrm{H}, \mathrm{CH}_{2}-\right.$ chain), $0.92-0.78\left(\mathrm{~m}, 6 \mathrm{H}, \mathrm{CH}_{2}-8\right.$ and $\left.\mathrm{CH}_{2}-\right) .{ }^{13} \mathrm{C} \mathrm{NMR}$ $\left(126 \mathrm{MHz}, \mathrm{CDCl}_{3}\right) \delta 179.6(\mathrm{COO}), 66.9$ (C-1), 53.2 $\left(\mathrm{NMe}_{3}\right), 39.2$ (C-2'), 32.4, 31.9, 29.50, 29.46, 29.3, 26.9 (3'), 26.4, 23.3 (C-2), 22.8, 22.7, $14.3\left(\mathrm{CH}_{3}-10 / \mathrm{CH}_{3}-6^{\prime}\right), 14.2$ $\left(\mathrm{CH}_{3}-10 / \mathrm{CH}_{3}-6\right)$ ') ${ }^{15} \mathrm{~N}$ NMR $\left(51 \mathrm{MHz}, \mathrm{CDCl}_{3}\right) \delta 49.8$ $\left(\mathrm{NMe}_{3}\right.$ ). HRMS (ESI+): calcd. for $\mathrm{C}_{13} \mathrm{H}_{30} \mathrm{~N}^{+}\left[\mathrm{M}^{+}\right] 200.2373$, found 200.2370. HRMS (ESI-): calcd. for $\left.\mathrm{C}_{10} \mathrm{H}_{19} \mathrm{O}_{2}{ }^{-}{ }^{-} \mathrm{M}^{-}\right]$ 171.1391, found 171.1386.

\section{Results and Discussion}

A series of quaternary ammonium carboxylates $N$-alkyl- $N, N, N$-trimethylammonium alkanecarboxylates were prepared according to two general procedures as presented on Figure 2.

In the first step of procedure $\mathrm{A}$, where the reaction mixture was heated at $80^{\circ} \mathrm{C}$ for 3 days, alkyltrimethylammonium chlorides (alkyl = hexyl, 3a; octyl, 3b; decyl, 3c) were obtained. Procedure A is followed by a cost effective approach to anion exchange in ethanolic solutions of $\mathrm{KOH}$ through precipitation of $\mathrm{KCl}$ (see Experimental Section for details) yielding alkyltrimethylammonium alkanecarboxylates (5a-e, Table in Figure 2). Even though the reported solubility of $\mathrm{KCl}$ in ethanol is very low $(0.034 \%)^{14}$ the final products of procedure A shown in Table 1 contained up to $3 \%$ of inorganic salt as determined by $\mathrm{AgNO}_{3}$ titration (0.6 $\left.\pm 0.5 \% \mathrm{Cl}^{-}\right)$and TG analysis $(2 \pm 1 \%)$. Presumably the presence of the product significantly increases solubility of $\mathrm{KCl}$ in ethanol. In fact, products are soluble in polar (water, methanol, ethanol, 1-butanol, acetone, ethyl acetate) and most non-polar (diethyl ether, $n$-hexane, toluene, dichloromethane, chloroform) solvents, making complete separation from $\mathrm{KCl}$ by precipitation impossible.

Therefore, the procedure B was developed as an alternative. Starting from dimethylamine (6) the long alkyl chain is introduced in the step before quaternization. Therefore, the soluble halide salts are easily washed away with water. Quaternization was successfully achieved with dimethyl carbonate $\left(\mathrm{Me}_{2} \mathrm{CO}_{3}\right)$, a common methylating agent enabling a facile purification method. The side products, methanol and $\mathrm{CO}_{2}$, are easily removed under reduced pressure. Jiang et al. used significant excess (5-10 eq) of $\mathrm{Me}_{2} \mathrm{CO}_{3}$ and relatively short reaction times $(5-7 \mathrm{~h}) .{ }^{8,9} \mathrm{We}$ extended the reaction time in attempt to reach quantitate yield with minimal excess of reactant. Anion exchange was performed with carboxylic acid followed by the removal of volatile byproducts. For analysis the products $(\mathbf{5 a}-\mathbf{f})$ were recrystallized from acetonitrile. Surfactants with longer alkyl chains to the ones in this work have been reportedly 


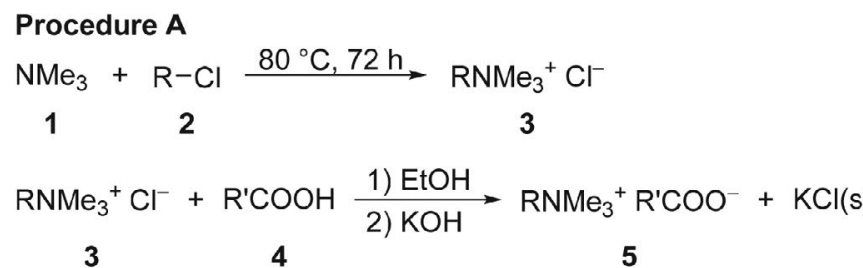

$$
\begin{aligned}
& \mathrm{R}=\mathrm{CH}_{3}-\left[\mathrm{CH}_{2}\right]_{\mathrm{m}}- \\
& \mathrm{R}^{\prime}=\mathrm{CH}_{3}-\left[\mathrm{CH}_{2}\right]_{\mathrm{n}}-
\end{aligned}
$$

\section{Procedure B}
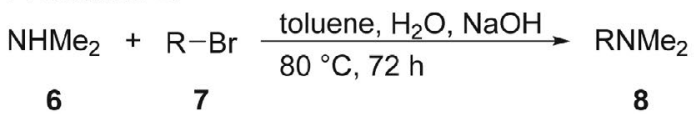
7

\begin{tabular}{ccc}
$\#$ & $\mathrm{~m}$ & $\mathrm{n}$ \\
\hline $\mathbf{5 a}$ & 5 & 8 \\
$\mathbf{5 b}$ & 7 & 8 \\
$\mathbf{5 c}$ & 9 & 8 \\
$\mathbf{5 d}$ & 7 & 6 \\
$\mathbf{5 e}$ & 9 & 6 \\
$\mathbf{5 f}$ & 9 & 4
\end{tabular}

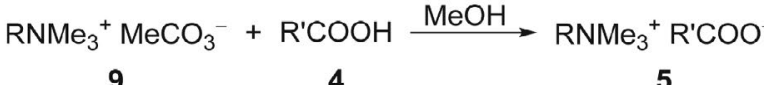

5

Figure 2. Reaction scheme for preparation of $N$-alkyl-N,N,N-trimethylammonium alkanecarboxylates according to procedures A and $\mathrm{B}$.

recrystallized from ethyl acetate or ethyl acetate-acetone mixture ${ }^{9,10}$ however compounds with shorter alkyl chains are soluble in both subsequently limiting recrystallizations to acetonitrile.

The compounds synthesized according to procedure B were characterized using standard NMR spectroscopy techniques, IR spectroscopy, HRMS.

The two methods thus enable the preparation of the same products in different number of reaction steps and of different purity. A simpler method A is more suitable for quick preparation of products in which the presence of inorganic salt does not affect its application. However, the first step of method B can be industrially replaced by catalytic alkylation of dimethylamine with alcohols ${ }^{15-17}$ thus method B can produce desired catanionic surfactants using a more environmentally friendly approach. Nevertheless, in the case where salts in final product could result in undesired properties, procedure $B$ is the method of choice.
From the obtained TG/DSC curves the effect of impurities on the thermal properties of studied catanionic surfactants was observed, explicitly the change in the melting point and the decomposition temperature as presented in Table 1.

Thermal analysis of products reveals very similar decomposition temperature for all products regardless of alkyl chain lengths (Table 1). From the TG curves (Figures S1 and S2 in Supporting Information) it is evident from the starting \% of mass that shorter alkyl chains increase hygroscopicity of the compound. However, this water is weakly bound as most samples obtained by procedure B were completely dehydrated at mere $70{ }^{\circ} \mathrm{C}$ except for $\mathbf{5 a}$ and $\mathbf{5 f}$ where water binding is stronger. Presence of $\mathrm{KCl}$ significantly increases the strength of binding of water as well as introduces a second step in the decomposition. This step is more pronounced the longer the alkyl chain on the anion thus we propose the formation of potassium carboxylate.

\begin{tabular}{|c|c|c|c|c|c|c|}
\hline \multirow{2}{*}{ Compound } & \multicolumn{2}{|c|}{ Alkyl chain length } & \multirow{2}{*}{ Method } & \multirow{2}{*}{ Yield/\% } & \multirow{2}{*}{$T_{\mathrm{m}} /{ }^{\circ} \mathrm{C}$} & \multirow{2}{*}{$T_{\mathrm{dec}}{ }^{\circ} \mathrm{C}$} \\
\hline & Cation & Anion & & & & \\
\hline \multirow[t]{2}{*}{$5 \mathbf{a}$} & 6 & 9 & A & 26 & 128 & 170 \\
\hline & & & B & 35 & / & 169 \\
\hline \multirow[t]{2}{*}{$5 \mathbf{b}$} & 8 & 9 & A & 53 & 144 & 170 \\
\hline & & & $\mathrm{B}$ & 63 & 176 & 180 \\
\hline \multirow[t]{2}{*}{$5 c$} & 10 & 9 & A & 55 & I & 174 \\
\hline & & & $\mathrm{B}$ & 72 & 172 & 181 \\
\hline \multirow[t]{2}{*}{$5 d$} & 8 & 7 & $\mathrm{~A}$ & 53 & 147 & 172 \\
\hline & & & B & 28 & I & 179 \\
\hline \multirow[t]{2}{*}{$5 e$} & 10 & 7 & A & 55 & l & 173 \\
\hline & & & $\mathrm{B}$ & 54 & 1 & 184 \\
\hline $5 f$ & 10 & 5 & $\mathrm{~B}$ & 13 & l & 178 \\
\hline
\end{tabular}

Table 1. Yields and thermal data for the prepared compounds by the two methods. 
For comparison TG/DSC curve of decyltrimethylammonium chloride ( $\mathbf{3 c}$ ) is also presented on Figures $\mathrm{S} 1$ and S2 indicating lower thermal stability of carboxylates. Stability is also somewhat lowered by $\mathrm{KCl}$ (Table 1). Melting point or phase transition was observed for some of the products. $\mathrm{KCl}$ lowers the temperature of this transition.

\section{Conclusions}

In the proposed salt-free procedure first alkyl trimethylammonium methylcarbonate is obtained and reacted with carboxylic acid. The side products of methanol and $\mathrm{CO}_{2}$ are easily removed under reduced pressure. In principle, salts composed of quaternary ammonium cations and most anions can be synthesized with this procedure. Reactants are inexpensive thus the procedure is potentially applicable in industrial production. An alternative procedure applying precipitation method is a viable alternative when inorganic impurities do not affect the application of the surfactant.

\section{Supplementary Material}

Copies of the IR and NMR spectra as well as additional figures on thermal analysis are available free of charge.

\section{Acknowledgements}

The financial support by the Slovenian Research Agency through Grants No. P1-0201, P1-0230 and P10134 is gratefully acknowledged. $\check{Z}$. M. is grateful to Slovenian Research Agency for the position of young researcher enabling him the doctoral study. Dr. Damijana Urankar from the Research Infrastructure Centre at the Faculty of Chemistry and Chemical Technology, University of Ljubljana, is acknowledged for HRMS analyses.

\section{References}

1. A. Khan, E. Marques, in: I. D. Robb (Ed.) Specialist Surfactants. Springer, Dordrecht, 1997

2. G. Kume, M. Gallotti, G. Nunes, J. Surfact. Deterg. 2008, 11, 1-11. DOI:10.1007/s11743-007-1047-1

3. P. Jokela, B. Joensson, A. Khan, J. Phys. Chem. 1987, 91, 32913298. DOI:10.1021/j100296a037

4. G. C. Kresheck, J. Phys. Chem. B 2009, 113, 6732-6735. DOI:10.1021/jp811048d

5. A. Kroflič, B. Šarac, M. Bešter-Rogač, J. Chem. Thermodyn. 2011, 43, 1557-1563. DOI:10.1016/j.jct.2011.05.015

6. A. Kroflič, B. Šarac, M. Bešter-Rogač, Langmuir 2012, 28, 10363-10371. DOI:10.1021/la302133q

7. L. L. Schramm, E. N. Stasiuk, D. G. Marangoni, Annu. Rep. Prog. Chem., Sect. C: Phys. Chem. 2003, 99, 3-48. DOI:10.1039/B208499F

8. Y. Jiang, T. Geng, Q. Li, J. Surfact. Deterg. 2012, 15, 67-71. DOI:10.1007/s11743-011-1289-9

9. H.-C. Yan, Q. Li, T. Geng, Y. Jiang, Y. Luo, Tenside Surf. Det. 2012, 49, 211-215. DOI:10.3139/113.110184

10. Y. Jiang, T. Geng, Q. Li, G. Li, H. Ju, J. Mol. Liq. 2015, 204, 126-131. DOI:10.1016/j.molliq.2015.01.026

11. P. Tundo, M. Selva, Acc. Chem. Res. 2002, 35, 706-716. DOI:10.1021/ar010076f

12. D. G. Oakenfull, D. E. Fenwick, Aust. J. Chem. 1973, 26, 2649-2658. DOI:10.1071/CH9732649

13. H. E. Gottlieb, V. Kotlyar, A. Nudelman, J. Org. Chem. 1997, 62, 7512-7515. DOI:10.1021/jo971176v

14. S. P. Pinho, E. A. Macedo, J. Chem. Eng. Data 2005, 50, 29-32. DOI:10.1021/je049922y

15. G. A. Kliger, L. S. Glebov, V. P. Ryzhikov, V. E. Shiryaeva, T. P. Popova, S. M. Loktev, Russ. Chem. Bull. 1987, 36, 1738. DOI:10.1007/BF00960149

16. M. H. S. A. Hamid, C. L. Allen, G. W. Lamb, A. C. Maxwell, H. C. Maytum, A. J. A. Watson, J. M. J. Williams, J. Am. Chem. Soc. 2009, 131, 1766-1774. DOI:10.1021/ja807323a

17. X. Cui, X. Dai, Y. Deng, F. Shi, Chem. Eur. J. 2013, 19, 36653675. DOI:10.1002/chem.201203417

\section{Povzetek}

Površinsko aktivne snovi v komercialnih produktih pogosto vsebujejo mešanice anionskih in kationksih surfaktantov, zato so bile dosedaj večinoma preiskovane vodne raztopine mešanic površinsko aktivnih snovi. Vendar pa so raziskave čistih katanionskih površinsko aktivnih snovi, ki se pogosto imenujejo katanionski surfaktanti brez soli, redke. Ena od težav je pridobivanje vzorcev $\mathrm{z}$ zahtevano čistostjo zaradi težkega ločevanja teh spojin od anorganskih soli. V tem delu predstavljamo alternativno metodo sinteze $\mathrm{z}$ dimetilkarbonatom kot alkilirnim sredstvom za pripravo alkil trimetilamonijevih alkankarboksilatov s srednjimi dolžinami alkilnih verig (6-10).

Except when otherwise noted, articles in this journal are published under the terms and conditions of the Creative Commons Attribution 4.0 International License 